\title{
Desafios e perspectivas à Pastoral Familiar a partir da Amoris Laetitia
}

\section{Challenges and perspectives to the Family Ministry from Amoris Laetitia}

Abimar Oliveira de Moraes

\section{Resumo}

O presente artigo dá continuidade à leitura kairológica do complexo relacionamento entre pastoral e família, na atualidade. Para tanto, se debruça sobre a Exortação Apostólica Amoris Laetitia do Papa Francisco. Destacaremos, em primeiro lugar, algumas características basilares da pastoral familiar hoje. Em seguida, nosso artigo vai analisar como Amoris Laetitia exige uma pastoral familiar que seja radicada no amor e na misericórdia e, por fim, falaremos da arte do acompanhamento a fim de que as famílias "tornem-se" cristãs.

Palavras-chave: Pastoral. Família. Transmissão da Fé. Francisco.

\begin{abstract}
This presente article continues performs a kairological interpretation on the complex relationship between pastoral and family in our current situation. Starting from Apostolic Exhortation Amoris Laetitia of the Pope Francis. We highlight, first, some basic characteristics of family ministry today. Then our article will analyze how Amoris Laetitia requires a family ministry that is rooted in love and mercy. Finally, we'll speak about the art of follow so that families "become" christians.
\end{abstract}

Keywords: Pastoral. Family. Transmission of the Faith. Francis. 


\section{Introdução}

Parece-nos ser possível já afirmar que a família encontra-se no centro das preocupações do Pontificado de Francisco. Por este motivo, deu início a um processo sinodal, dividido em duas sessões. Para preparar cada uma das sessões, o Santo Padre expressou o desejo de que fossem consultadas as conferências episcopais, os teólogos e os fiéis de todas as dioceses.

No desejo de levar em consideração as realidades concretas vividas pelas famílias nos diversos contextos e nas diversas culturas, o Papa traz consigo o propósito de que a Igreja Católica tenha uma preocupação em, de maneira nova, anunciar o evangelho às famílias. As famílias devem poder acolhê-lo novamente como revelação da sua vocação primordial, caminho de salvação, fonte de renovação e de crescimento para que elas possam, enfim, dedicar-se à evangelização. No processo sinodal, realiza-se, assim, aquilo que Francisco mesmo anunciava na exortação apostólica Evangelii Gaudium:

Não se deve pensar que o anúncio do evangelho tenha de ser transmitido sempre com determinadas fórmulas pré-estabelecidas ou com palavras concretas que exprimam um conteúdo absolutamente invariável. Transmite-se com formas tão diversas que seria impossível descrevê-las ou catalogá-las, e cujo sujeito coletivo é o povo de Deus com seus gestos e sinais inumeráveis. [...] $\mathrm{O}$ que se deve procurar é que a pregação do Evangelho, expressa com categorias próprias da cultura onde é anunciado, provoque uma nova síntese com essa cultura. ${ }^{1}$

É interessante sublinhar o modo como o Papa, juntamente com os demais organizadores do processo sinodal, envolvem os diversos componentes da igreja nesta vasta iniciativa eclesial. Por bem duas vezes, os fiéis foram convidados a exprimir-se sobre suas experiências, suas evoluções e suas dificuldades familiares. A sessão extraordinária do sínodo, em outubro de 2014, teve como ponto de partida as respostas da primeira consulta. Os debates dos padres sinodais permitiram definir novas questões que foram reenviadas ao Povo de Deus para avançar na reflexão e nas propostas.

Sobre certos aspectos, a Exortação Apostólica Pós-Sinodal Amoris Laetitia sobre o amor na família conclui este processo. Contudo, lendo as primeiras

\footnotetext{
${ }^{1}$ FRANCISCO. "Exortação Apostólica Evangelii Gaudium sobre o anúncio do Evangelho no mundo actual”. Disponível em: <www.vatican.va>. Acesso em 26 de setembro de 2016, n. 129.
} 
páginas da Exortação, já percebemos que ela não quer ser uma conclusão, mas sim o início de uma longa estação de discernimento, debates e avanços:

O caminho sinodal permitiu analisar a situação das famílias no mundo atual, alargar a nossa perspectiva e reavivar a nossa consciência sobre a importância do matrimônio e da família. Ao mesmo tempo, a complexidade dos temas tratados mostrou-nos a necessidade de continuar a aprofundar, com liberdade, algumas questões doutrinais, morais, espirituais e pastorais. ${ }^{2}$

O itinerário que inicia-se com esse processo sinodal mobiliza, contemporaneamente, o magistério, através, principalmente, das reflexão das conferências episcopais, o sensus fide $i^{3}$ do Povo de Deus e o trabalho dos teólogos e teólogas. A fecundidade desse tempo de discernimento dependerá da boa articulação entre estas três instâncias; por isso, mesmo, Francisco recorda:

O tempo é superior ao espaço, quero reiterar que nem todas as discussões doutrinais, morais ou pastorais devem ser resolvidas através de intervenções magisteriais. Naturalmente, na Igreja, é necessária uma unidade de doutrina e práxis, mas isto não impede que existam maneiras diferentes de interpretar alguns aspectos da doutrina ou algumas consequências que decorrem dela. ${ }^{4}$

A atenção à Amoris Laetitia gera, portanto, a necessidade de continuarmos a refletir teologicamente sobre a vocação e a missão da família na igreja e no mundo contemporâneo. Não cabe à teologia dizer tudo, nem pronunciar a palavra definitiva sobre as problemáticas que permanecem abertas, mas, teólogos e teólogas são chamados a exercer sua responsabilidade específica, em relação com o magistério, a fim de contribuírem especificamente nesse momento de discernimento até chegarmos ao acolhimento da "verdade completa”, para usar a expressão adotada por Francisco:

\footnotetext{
${ }^{2}$ FRANCISCO. Exortação apostólica pós-sinodal Amoris Laetitia sobre o amor na família. Loyola: São Paulo, 2016, n. 2. O grifo é nosso.

${ }^{3}$ Sobre o sensus fidei ver: CONGREGAÇÃO PARA A DOUTRINA DA FÉ. "Instrução Donum Veritatis sobre a vocação eclesial do teólogo". Disponível em: <www.vatican.va>. Acesso em 26 de setembro de 2016, n. 35.

${ }^{4}$ AL, n. 3 .
} 
Assim há de acontecer até que o Espírito nos conduza à verdade completa (cf. Jo 16,13), isto é, quando nos introduzir perfeitamente no mistério de Cristo e pudermos ver tudo com o seu olhar. ${ }^{5}$

Esse processo de discernimento se inscreve no tempo da igreja sempre em busca da verdade que se revela nas Escrituras e na Tradição, confrontada, porém, com a pluralidade dos espaços sócio-culturais particulares nos quais a verdade deve ser anunciada, por isso:

Em cada país ou região, é possível buscar soluções mais inculturadas, atentas às tradições e aos desafios locais. De fato, "as culturas são muito diferentes entre si e cada princípio geral (...), se quiser ser observado e aplicado, precisa de ser inculturado". ${ }^{6}$

Para a fecundidade de sua missão o magistério, a quem compete a custódia da autenticidade cristã e a unidade em matéria de fé e de moral, deve permanecer constantemente em diálogo com os teólogos e teólogas, ${ }^{7}$ uma vez que compete à teologia a interpretação dos ensinamentos magisteriais passados e atuais, a colocação dos mesmos no contexto total da verdade revelada e a promoção da melhor inteligência com o auxílio da hermenêutica. ${ }^{8}$ Nesse sentido, as tensões são legítimas, mas é preciso evitar que elas sejam interpretadas como se teologia e magistério fossem inimigos e opositores. As tensões servem como força vital e estímulo para construir comunitariamente e dialogicamente a "verdade completa". ${ }^{9}$ Tal diálogo frutuoso entre magistério e teologia é augurado pelo próprio Francisco:

A Igreja, comprometida na evangelização, aprecia e encoraja o carisma dos teólogos e o seu esforço na investigação teológica, que promove o diálogo com o mundo da cultura e da ciência. Faço apelo aos teólogos para que cumpram este serviço como parte da missão salvífica da Igreja. Mas, para isso, é necessário que tenham a peito a finalidade evangelizadora da Igreja e da própria teologia, e não se contentem com uma teologia de gabinete. ${ }^{10}$

\footnotetext{
${ }^{5}$ AL, n. 3 .

${ }^{6}$ AL, n. 3 .

${ }^{7}$ Donum veritatis, n. 24.

${ }^{8}$ COMISSIONE TEOlOGICA INTERNAZIONALE. "Magistero e teologia". Disponível em: $<$ www.vatican.va $>$. Acesso em: 26 de setembro de 2016, tesi 8, n. 2.

${ }^{9}$ Magistero e teologia, tesi 9.

${ }^{10}$ EG, n. 133.
} 
O presente artigo dá continuidade à reflexão sobre o complexo relacionamento entre teologia pastoral e família, na atualidade, que outrora iniciamos. ${ }^{11}$ Por ocasião do começo do processo sinodal tentamos analisar alguns desafios catequéticos a partir do recente magistério da Igreja, especialmente, tendo como ponto de referência a Familiaris Consortio de São João Paulo II. Agora, nosso ensejo é, partindo da Amoris Laetitia de Francisco, refletir sobre algumas características necessárias a uma pastoral familiar que intencione oferecer às famílias a possibilidade de um protagonismo ativo ${ }^{12}$ no campo da transmissão da fé no hodierno. Destacaremos, em primeiro lugar, algumas características basilares da pastoral familiar hoje. Em seguida, nosso artigo vai analisar como Amoris Laetitia exige uma pastoral familiar que seja radicada no amor e na misericórdia e, por fim, falaremos da arte do acompanhamento a fim de que as famílias "tornem-se" cristãs.

\section{A pastoral familiar hoje: algumas características basilares}

O caminho de vida familiar não é retilíneo, mas sofre com as incertezas e os riscos da crise sócio-cultural do momento histórico atual. ${ }^{13}$ A relação entre os cônjuges e a dos pais com os filhos, assim como as relações com os demais membros da família, representam hoje uma aventura, devido à complexidade que as entranham e ao pluralismo de visões e planejamentos que a família conhece. A fragilidade dos vínculos e o fato de outorgar a máxima importância à emotividade prejudicam hoje gravemente os esposos, que muitas vezes experimentam o isolamento e, até mesmo, uma solidão vivida por ambos. Tal solidão acaba, em muitas ocasiões, sendo estendida aos filhos que desejariam maior presença e relação com seu pais. ${ }^{14}$

Por isso, em nossos dias, uma pastoral familiar missionária capaz de:

Não se contentar com um anúncio puramente teórico e desligado dos problemas reais das pessoas. A pastoral familiar deve fazer experimentar que o Evangelho da família é resposta às expectativas mais profundas da

\footnotetext{
${ }^{11}$ Cf. MORAES, A. "Família, 'lugar primeiro' da transmissão da fé: desafios catequéticos a partir do magistério". Perspectiva Teológica 131 (2015), pp. 71-88.

${ }^{12}$ Cf. AL, n. 287.

${ }^{13}$ A Exortação dedica todo o segundo capítulo à realidade e aos desafios da família hoje: AL, nn. 31-57.

${ }^{14}$ Cf. EG, n. 66.
} 
pessoa humana: a sua dignidade e plena realização na reciprocidade, na comunhão e na fecundidade..$^{15}$

O Papa recorda que em sua atuação pastoral familiar a igreja deve ter como referência o Evangelho, isto é, o comportamento de Jesus expresso tanto em sua vida como em seus ensinamentos. Ao olharmos para Jesus, nos evangelhos, vemos como foi exigente na doutrina referida ao matrimônio (Mt 19,1-9), ao mesmo tempo, exercitou sempre nas situações concretas a verdadeira misericórdia. Assim aparece claramente, dentre outros, no seu encontro com a mulher da Samaria (Jo 4,1-30) e com a adúltera (Jo 8,1-11). Jesus, mostrando seu amor a estas mulheres, as conduz ao arrependimento e à conversão como condição necessária para o perdão. Podemos assim dizer que Jesus, em sua vida pública, olhou com amor e ternura para as mulheres e os homens, acompanhando seus passos com verdade, paciência e misericórdia ao anunciar as exigências do Reinado de Deus.

Por essa razão, na pastoral da família tudo deve ser interpretado a partir do amor compassivo. Reiteradas vezes, Francisco, em seu pontificado, nos recorda que a misericórdia é o centro do Evangelho. Ele faz questão de contextualizar que a leitura da Exortação deve ser feita dentro do espírito jubilar da misericórdia:

Esta Exortação adquire um significado especial no contexto deste Ano Jubilar da Misericórdia, em primeiro lugar, porque a vejo como uma proposta para as famílias cristãs, que as estimule a apreciar os dons do matrimônio e da família e a manter um amor forte e cheio de valores como a generosidade, o compromisso, a fidelidade e a paciência; em segundo lugar, porque se propõe a encorajar todos a serem sinais de misericórdia e proximidade para a vida familiar, onde esta não se realize perfeitamente ou não se desenrole em paz e alegria. ${ }^{16}$

Ouvindo Amoris Laetitia, a Igreja é chamada a acolher as pessoas tal como são e vivem, para alentar e sustentar sua busca da verdade na misericórdia. Ela mesma é "família de famílias". ${ }^{17}$ Podem nos ser úteis, duas imagens

\footnotetext{
${ }^{15}$ AL, n. 201.

${ }^{16} \mathrm{AL}, \mathrm{n} .5$. O grifo é nosso.

${ }^{17}$ AL, n. 87.
} 
que o Papa portenho gosta muito de usar, podemos pensar como há de ser a pastoral das famílias hoje: o hospital de campanha ${ }^{18} \mathrm{e}$ a sinfonia.

O "hospital de campanha" é uma descrição certeira ao que a Igreja, no nosso mundo, está sendo chamada a ser. Aplicada ao matrimônio e à família, significa atrever-se a colocar em primeiro plano as dificuldades concretas que atravessam aqueles que contraem o matrimônio e as percebidas pelos distintos agentes de pastoral familiar quando anunciam e testemunham o "evangelho da família" ${ }^{19}$ numa sociedade tantas vezes distanciada dos valores mais genuinamente humanos e cristãos.

A imagem significa reconhecer-se como depositários de uma "capacidade de curar" as feridas da vida humana. Refletir sobre e atuar pastoralmente no campo do matrimônio e da família nos permite voltar a tomar consciência da força sanadora da Palavra de Deus e da função que a Igreja exerce enquanto "sacramento universal da salvação". ${ }^{20}$ Neste "hospital", a medicina fundamental é a graça que outorga ao ser humano suas possibilidades mais reais. Por isso, a Igreja não pode se contentar com um anúncio meramente teórico, abandonando às famílias em sua tarefa de alcançá-lo ou não, mas deve se pôr ao lado das famílias concretas, oferecendo a ajuda necessária para que o "ideal" se transforme em "real e possível", encarnado na própria vivência familiar. Eis a urgência da pastoral familiar.

A segunda imagem é a da "sinfonia". Esta imagem aplicada à missão da Igreja com relação ao matrimônio e à família resulta particularmente sugestiva, na medida em que a pastoral familiar buscar a plenitude da beleza, em suas distintas dimensões, mas através da execução de um todo harmônico. Uma sinfonia não se realiza através da execução simultânea de todos os instrumentos que compõe uma única e mesma orquestra. Mas cada instrumento precisa encontrar o seu tempo de atuação, precisa encontrar o momento de expressarse e o momento de silenciar-se, em vista da harmonia sinfônica. Por isso, ao falar das fragilidades relativas à família, o Papa evoca o princípio da gradualidade na pastoral, já proposto pelo seu antecessor, na Familiaris Consortio:

Nesta linha, São João Paulo II propunha a chamada "lei da gradualidade", ciente de que o ser humano "conhece, ama e cumpre o bem moral segundo

\footnotetext{
${ }^{18}$ Cf. AL, n. 291.

${ }^{19}$ Cf. AL, nn. 200-204.

${ }^{20}$ CONCÍLIO VATICANO II. Constituição Dogmática Lumen Gentium sobre a Igreja. São Paulo: Paulinas, 1998, n. 1.
} 
diversas etapas de crescimento". Não é uma "gradualidade da lei", mas uma gradualidade no exercício prudencial dos atos livres em sujeitos que não estão em condições de compreender, apreciar ou praticar plenamente as exigências objetivas da lei. ${ }^{21}$

Quem tem experiência de vida familiar e os que aceitam ajudá-la pastoralmente devem estar conscientes de que a grande tarefa é buscar o crescimento gradual até a plenitude do amor. Isto requer sempre impulsos criativos e constância no propor, sem impor. O processo de acompanhamento pastoral das famílias visa à consecução de sua vocação própria que é a santidade, mas tal santidade precisa ser entendida em perspectiva dinâmica e progressiva. Eis uma outra urgência da pastoral familiar.

\section{Uma pastoral familiar fundada no amor}

A vocação ao amor que Deus dá a cada pessoa parece ser a coluna vertebral sobre a qual a Exortação constrói a sua visão pastoral da família. O amor é entendido como a vocação fundamental da pessoa humana, mas que precisa ser auxiliada em seu processo de crescimento:

Não poderemos encorajar um caminho de fidelidade e doação recíproca, se não estimularmos o crescimento, a consolidação e o aprofundamento do amor conjugal e familiar. De fato, a graça do Sacramento do Matrimônio destina-se, antes de tudo, "a aperfeiçoar o amor dos cônjuges". ${ }^{22}$

Assim, a pastoral familiar pode ser definida como o acompanhamento feito pela Igreja à pessoa na realização de sua vocação primordial ao amor. Deus está na gênese, no desenvolvimento e na plenitude do caminho vocacional do amor. Sendo o amor o centro de todo o sistema pastoral da família, ${ }^{23}$ ela não pode conformar-se com um enfoque principalmente normativo-institucional, mas sua tarefa primeira é ajudar no amadurecimento, aprofundar e intensificar a experiência e desejo de amor, mesmo quando o matrimônio realiza-se "de forma parcial e analógica [...] a Igreja não deixa de valorizar os (seus) elementos constitutivos". ${ }^{24}$

\footnotetext{
${ }^{21}$ AL, n. 295.

${ }^{22}$ AL, n. 89.

${ }^{23}$ Por este motivo Amoris Laetitia dedica expressamente 109 parágrafos ao tema do amor no matrimônio (cf. AL, nn. 89-164) e em sua dimensão de fecundidade (cf. AL, nn. 165-198).

${ }^{24}$ AL, n. 292.
} 
O tema da centralidade do amor está presente no magistério e se compreende, de maneira muito clara, à luz da primeira encíclica de São João Paulo II, onde ele estabelece que o ser humano não pode viver sem o amor, pois, sem ele, permaneceria incompreensível para si mesmo. ${ }^{25}$ Por isso, lendo o hino à caridade de São Paulo (cf. 1Cor 13,4-7), Francisco dirá que o genuíno amor conjugal é paciente,,${ }^{26}$ é serviçal, ${ }^{27}$ não é invejoso, ${ }^{28}$ não é arrogante e nem orgulhoso, ${ }^{29}$ é amável, ${ }^{30}$ é desprendido, ${ }^{31}$ não é violento, ${ }^{32}$ é perdão, ${ }^{33}$ é alegre,${ }^{34}$ tudo desculpa,${ }^{35}$ confia,${ }^{36}$ espera ${ }^{37}$ e tudo suporta. ${ }^{38}$ Superando os sentimentos egoístas e buscando os caminhos da paz, assim uma família se edifica no amor, como uma casa que não desmorona, comunidade de pessoas fortes:

A pessoa forte é aquela que pode quebrar a cadeia do ódio, a cadeia do mal (...). Alguém deve ter bastante fé e moralidade para a quebrar e injetar dentro da própria estrutura do universo o elemento forte e poderoso do amor. ${ }^{39}$

O amor é a via privilegiada pela qual a família pode alcançar a sua plenitude. Por isso, a pastoral familiar precisa dedicar uma atenção toda especial à educação, à afetividade, que supere o analfabetismo afetivo como incapacidade de ler as próprias emoções e sentimentos e de escrever com os sentimentos e emoções uma história coerente e sensata:

A maturidade chega a uma família, quando a vida emotiva dos seus membros se transforma em uma sensibilidade que não domina nem

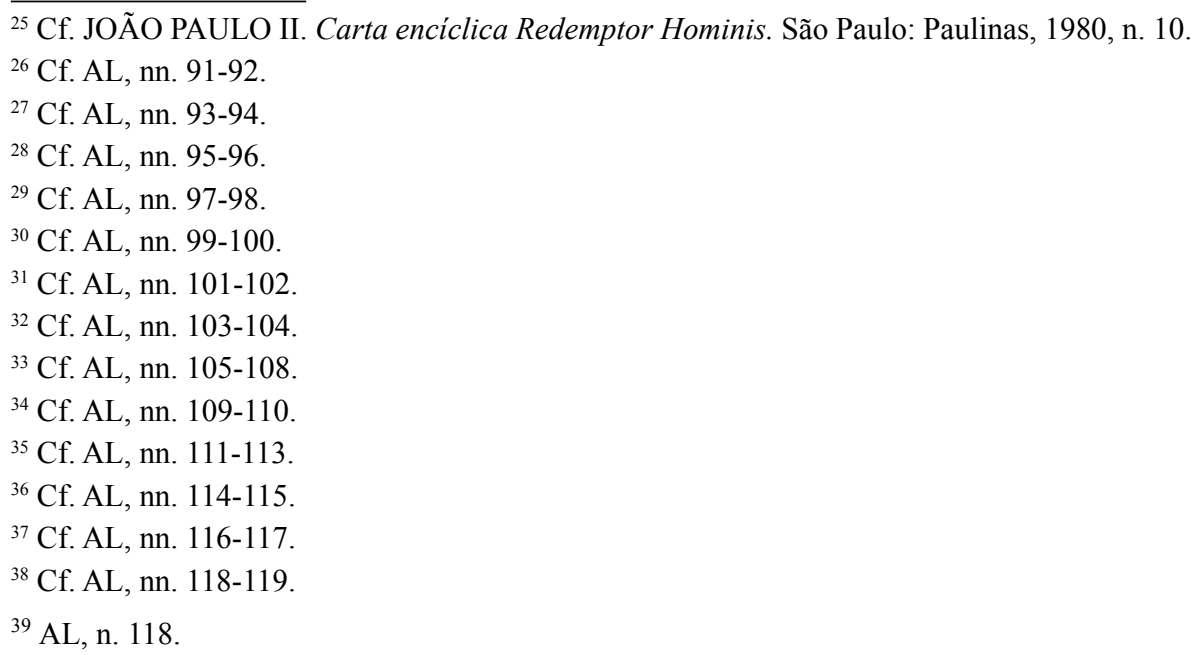


obscurece as grandes opções e valores, mas segue a sua liberdade, brota dela, enriquece-a, embeleza-a e torna-a mais harmoniosa para bem de todos. ${ }^{40}$

A Igreja não pode ter medo de desempenhar o papel de educadora da afetividade, desde que o faça propondo um caminho realista de amadurecimento que seja sustentado e alentado pelo processo de construção da plenitude do amor. Assim, o respeito pelos "tempos afetivos" de cada pessoa envolvida na experiência familiar não é contrário ao amor, tal como a Igreja o concebe, mas torna-se um ingrediente necessário para que uma pessoa seja edificada e dirigida até a comunhão com as outras pessoas por meio de ações e práticas concretas. A vocação ao amor se desdobra, deste modo, nas mais distintas experiências familiares: filiação, ${ }^{41}$ fraternidade, ${ }^{42}$ esponsabilidade ${ }^{43}$ e paternidade-maternidade..$^{44}$ Cada uma destas distintas experiências familiares supõe um caminho de amadurecimento afetivo, no amor.

Francisco sublinha a necessidade de formar as novas gerações para que vivam seriamente o amor, não com pretensões individualistas baseadas somente no prazer e no "desfrute". É preciso que a novas gerações sejam ajudadas a crer novamente no amor autêntico, fértil e perpétuo como a única maneira de sair de si mesmos, para abrir-se ao outro, para afugentar a solidão, para viver a vontade de Deus. As novas gerações:

Devem poder captar o fascínio de uma união plena que eleva e aperfeiçoa a dimensão social da vida, confere à sexualidade o seu sentido maior, ao mesmo tempo que promove o bem dos filhos e lhes proporciona o melhor contexto para o seu amadurecimento e educação. ${ }^{45}$

Compete à pastoral familiar a tarefa de ajudar os jovens no processo de compreensão que o matrimônio é um espaço no qual se manifesta o amor divino, espaço sacro da vida e, por isso, espaço de unidade e de indissolubilidade, espaço aonde o ser humano ama em profundidade.

\footnotetext{
${ }^{40}$ AL, n. 146.

${ }^{41}$ Cf. AL, nn. 188-190

${ }^{42}$ Cf. AL, nn. 194-195.

${ }^{43}$ Cf. AL, nn. 120-141.

${ }^{44}$ Cf. AL, nn. 172-177.

${ }^{45}$ AL, n. 205.
} 
A pastoral familiar consiste em ajudar cada pessoa a viver a sua vocação ao amor. Segundo uma antropologia integral, o amor é a origem e o fim da existência humana. Por isso, o amor é uma realidade espiritual, diretamente vinculada à inteligência e à vontade. Por esta razão, inteligência e vontade precisam ser educadas pela graça e iluminadas pela fé, são elas que devem dirigir a vida humana através do amor. Os estímulos inferiores têm, é claro, uma função importante na natureza do ser humano, porém é preciso que eles permaneçam em seus lugares, sem usurpar o âmbito destas duas potências superiores.

A sexualidade não é um recurso para compensar ou entreter, mas trata-se de uma linguagem interpessoal onde o outro é tomado a sério, com o seu valor sagrado e inviolável. [...] Neste contexto, o erotismo aparece como uma manifestação especificamente humana da sexualidade. [...] O erotismo mais saudável, embora esteja ligado a uma busca de prazer, supõe a admiração e, por isso, pode humanizar os impulsos. ${ }^{46}$

Hoje, sem dúvida, a pessoa não é governada pelo espírito, mas por suas dimensões inferiores, isto é, pelos instintos. A sensibilidade, o gosto, o emocional e as sensações dirigem hoje a maioria dos atos humanos. A pastoral familiar precisa ajudar as famílias a alcançar a plenitude de vida humana e cristã. Neste cenário cultural, um importante desafio para a Igreja encontra-se em ajudar os matrimônios a amadurecerem em sua dimensão emocional e em seu desenvolvimento afetivo fomentando o diálogo, a virtude e a confiança no amor misericordioso de Deus.

\section{Uma pastoral familiar a partir da misericórdia}

Amoris Laetitia rende um louvor às famílias que conseguem permanecer fiéis aos do matrimônio cristão:

Com íntima alegria e profunda consolação, a Igreja olha para as famílias que permanecem fiéis aos ensinamentos do Evangelho, agradecendo-lhes pelo testemunho que dão e encorajando-as. Com efeito, graças a elas, torna-se credível a beleza do matrimônio indissolúvel e fiel para sempre. ${ }^{47}$

\footnotetext{
${ }^{46}$ AL, n. 151.

${ }^{47}$ AL, n. 86.
} 
Nessas palavras, vemos como Francisco apoia e anima as famílias que, não obstante as dificuldades de cada dia, dão cotidianamente um grande testemunho de fidelidade a Deus e aos ensinamentos da Igreja.

Ao mesmo tempo, é preciso acompanhar, discernir e integrar as fragilidades das pessoas e das famílias feridas. A Igreja não pode apresentar somente um ideal de família que para alguns pode resultar uma meta inalcançável e frustrante, mas sim, oferecer um caminho através do qual seja possível aprender a viver e crescer como família. Pois, no seio da família, experimentam-se alegrias e tribulações, afetos profundos e relações conflituosas.

A Igreja deve acompanhar, com atenção e solicitude, os seus filhos mais frágeis, marcados pelo amor ferido e extraviado, dando-lhes de novo confiança e esperança. ${ }^{48}$

Com os olhos misericordiosos de Jesus, a Igreja deve promover uma valorização equilibrada da realidade, capaz de advertir as ameaças às famílias, mas, ao mesmo tempo, capaz de advertir como o Espírito continua atuando na história. Já o Concílio Vaticano II estabeleceu o princípio de valorizar equilibradamente as alegrias e tristezas, esperanças e angústias do nosso tempo. ${ }^{49}$ Com relação à família, a Gaudium et spes reconheceu que fenômenos antigos e novos obscurecem a dignidade do matrimônio, mas, por outro lado, é possível perceber novas possibilidades para fomentar a experiência familiar. ${ }^{50}$

A Igreja deve estar consciente da fragilidade de muitos de seus filhos e filhas em percorrer o caminho da fé:

Portanto, sem diminuir o valor do ideal evangélico, é preciso acompanhar, com misericórdia e paciência, as possíveis etapas de crescimento das pessoas, que se vão construindo dia após dia. [...] A todos deve chegar a consolação e o estímulo do amor salvífico de Deus, que opera misteriosamente em cada pessoa, para além dos seus defeitos e das suas quedas. ${ }^{51}$

\footnotetext{
${ }^{48}$ AL, n. 291.

${ }^{49}$ CONCÍLIO VATICANO II. Constituição pastoral Gaudium et spes sobre a Igreja no mundo de hoje. São Paulo: Paulinas, 1998, n. 1.

${ }^{50} \mathrm{GS}$, n. 47.

${ }^{51}$ EG, n. 44.
} 
Manifestar e difundir a misericórdia de Deus às famílias, é uma meta fundamental da pastoral familiar que se deixa interpelar pelo Evangelho e que respeita as diferenças sócio-culturais dos novos tempos. Esta se esforçaria em ser uma pastoral capaz de transmitir a Boa Notícia com uma linguagem atraente e alegre a todas as famílias, independentemente da situação em que se encontram, sem ater-se às suas diversas condições, porque a misericórdia de Deus acolhe incondicionalmente.

Tal acolhida incondicional faz com que a Igreja seja família de famílias, casa para todos. A Igreja não somente "ajuda" às famílias, mas ela mesma se configura como família ou, melhor ainda, como mãe capaz de dar a primazia à hospitalidade incondicional. Entendendo-se, portanto, não como "casa de poucos", mas "morada de todos":

Creio sinceramente que Jesus Cristo quer uma Igreja atenta ao bem que o Espírito derrama no meio da fragilidade: uma Mãe que [...] não renúncia ao bem possível, ainda que corra o risco de sujar-se com a lama da estrada. ${ }^{52}$

A misericórdia é conceito-chave para entender a eclesiologia do Papa Bergoglio e, ao mesmo tempo, os esforços pastorais que daí derivam:

Não podemos esquecer que a misericórdia não é apenas o agir do Pai, mas torna-se o critério para entender quem são os verdadeiros filhos. [...] Toda sua ação pastoral [da Igreja] deveria estar envolvida pela ternura com que se dirige aos crentes; no anúncio e testemunho que oferece ao mundo, nada pode ser desprovido de misericórdia. ${ }^{53}$

A Igreja é autêntica casa de Deus quando se faz presente nos lugares da dor, da divisão ou da confusão. Nessas periferias, a Igreja se apresenta como "hospital de campanha" para acolher, dar calor, atender e curar. Assim, Francisco vê a Igreja: como uma comunidade que não se perde em escrúpulos e nem em mesquinhezes, mas que prima pela proximidade junto às famílias feridas, escutando-as e consumindo suas energias para curá-las.

\footnotetext{
${ }^{52}$ AL, n. 308.

${ }_{53}^{53}$ AL. n. 310.
} 


\section{Acompanhar as famílias para que sejam famílias cristãs}

Há muitos séculos, já se dizia que "os cristãos se fazem, não nascem". Para "tornar-se" algo novo é preciso passar por um processo de iniciação que envolve mais do que conhecer doutrinas. A pessoa nova que vai emergir como seguidora de um caminho, sem dúvida, se compromete com seu conhecimento, mas também, com suas emoções, suas opções de vida, suas escolhas. Diz o Documento de Aparecida: "não se começa a ser cristão por uma decisão ética ou uma grande ideia, mas pelo encontro com um acontecimento, com uma Pessoa, que dá novo horizonte à vida e, com isso, uma orientação decisiva" ${ }^{54}$

Se isto vale para um indivíduo, vale de modo análogo, para a família. Por esta razão, elas precisam ser acompanhadas até que sejam capazes de se expressarem como famílias cristãs. Por isto, o acompanhamento requer proximidade..$^{55}$ Acompanhar verdadeiramente é uma arte que não se aprende de maneira automática, mas que exige um profundo trabalho interior para saber estar próximo ao outro. Antes de tudo, acompanhar as famílias é tornar-se companheiros delas, entendendo-as como "solo sagrado" que exige temor e reverência. Acompanhar é caminhar com o outro num ritmo sanador feito pela proximidade, com um olhar respeitoso, com uma escuta compassiva e com uma palavra de alento.

A lógica da integração constitui a chave do [...] acompanhamento pastoral, para que não somente saibam pertencem [sic!] ao Corpo de Cristo que é a Igreja, mas possam fazer uma experiência feliz e fecunda da mesma. ${ }^{56}$

O acompanhamento nos coloca diante do mistério do outro, ${ }^{57}$ por esta razão, a ciência do acompanhamento não está regida pela lógica do "dar uma lição" ou colocar-se como modelo a ser imitado. O acompanhamento nos coloca na lógica da suma confiança de que é Deus quem move os corações, não a nossa persuasão ou insistência.

Uma sensibilidade que a pastoral familiar é chamada a desenvolver con-

\footnotetext{
${ }^{54}$ CELAM. Documento de Aparecida. Texto conclusivo da V Conferência Geral do Episcopado Latino-americano e do Caribe. Brasília/São Paulo/São Paulo: CNBB/Paulus/Paulinas, 2007, n. 12.

${ }^{55}$ Cf. EG, n. 171.

${ }^{56}$ AL, n. 299.

${ }^{57}$ Cf. EG, n. 172.
} 
siste no identificar os elementos positivos presentes nas assim chamadas "situações irregulares". Isto faz com que sejamos capazes de indicar, naquelas situações, os elementos construtivos, os elementos da vida convivial que podem levar a uma maior abertura ao Evangelho em sua plenitude. É preciso afrontar todas essas situações de maneira construtiva, tratando-se de transformá-las em oportunidade para a integração à luz do Evangelho, acompanhando-as com paciência e delicadeza, uma vez que:

O caminho da Igreja é o de não condenar eternamente ninguém; derramar a misericórdia de Deus sobre todas as pessoas que a pedem com coração sincero (...). Porque a caridade verdadeira é sempre imerecida, incondicional e gratuita. ${ }^{58}$

A arte do acompanhamento é complexa e desafiante, pois requer uma formação profunda e uma lenta maturação, porém, acima de tudo, é um dom da misericórdia de Deus que só pode ser realizado a partir da consciência maternal da Igreja.

Amoris Laetitia assinala a necessidade do acompanhamento durante os primeiros anos do matrimônio, ${ }^{59}$ especialmente no início da criação/educação dos filhos, quando se apresentam maiores desafios à entrega mútua dos cônjuges e o serviço compartilhado em favor da prole. A verdadeira pastoral familiar começa quando a família se constitui. Este é o momento em que, tanto as demais famílias da comunidade eclesial quanto os ministros ordenados devem saber acompanhar com sensibilidade e naturalidade evangélica aos esposos que se encontram nessa nova situação de vida.

"Constituir família" é uma velha atividade humana, mas que vai muito além de proporcionar alimento, vestido, teto e outros elementos de primeira necessidade. Implica criar uma atmosfera particular em casa, empregando aqueles elementos que produzem um sentido de pertença, de acolhida e de amor. Uma vez que nos encontramos diante de uma mudança radical no marco em que concebemos nossas atividades pastorais, podemos pensar que os membros envolvidos na pastoral familiar devem ajudar a famílias a verem o Reinado de Deus na vida quotidiana.

\footnotetext{
${ }^{58}$ AL, n. 296.

${ }^{59}$ Cf. AL, nn. 217-222.
} 


\section{Conclusão}

Por vontade de Francisco o processo sinodal desenvolveu-se num espaço de grande liberdade: os padres sinodais foram convidados a tomar a palavra livremente e a exprimirem com franqueza, ainda que isto tenha custado conflitos e contraposições. Tais conflitos, se vividos na caridade cristã, mostram-se fecundos e capazes de manifestar a presença do Espírito Santo, dom necessário para percebermos os caminhos na história a serem percorridos.

O tema do processo sinodal era espinhoso porque estava em jogo, não tanto uma disciplina diversa acerca do matrimônio, da família, da sexualidade, mas sim, a imagem de Deus, uma imagem que nós cristãos conhecemos somente no rosto de Jesus Cristo que nos fez conhecer esta imagem. Estava em jogo o rosto de Deus misericordioso e compassivo, revelado por Jesus através de suas palavras e ações, que jamais castigaram os pecadores, mas perdoaramlhes cada vez que a um deles encontrava.

O nó família-matrimônio suscitou no processo sinodal dificuldades e conflitualidades, resistências e, até mesmo, animosidade em diversos setores da Igreja, revelando o peso da "tradição de proveniência" e evocando, até mesmo, em alguns o espectro do cisma. Em Amoris Laetitia, o Papa Francisco guiou a Igreja a uma certa clareza sobre algumas temáticas de fundo, ao afirmar uma linha de misericórdia como atitude basilar para a pastoral familiar.

A Exortação não contradiz as palavras de Jesus a respeito da fidelidade matrimonial contida nos textos evangélicos e no epistolário paulino. Mas nos convidam a interpretar as palavras de Jesus como um anúncio, uma boa notícia e não como uma "lei" que transforma Jesus num mestre rigorista dos seus contemporâneos. Compreendendo-as como "anúncio", Amoris Laetitia retomará as palavras de Jesus, mas com o desejo de realizar um discernimento das situações concretas do hodierno.

$\mathrm{O}$ anúncio do matrimônio cristão é claro, exigente, porque na relação homem-mulher, que vivem uma história de amor, que estão ligados por uma aliança, está simbolizada a aliança fiel entre Deus e o seu Povo. Contudo, é preciso ter viva a lembrança de que nós não somos capazes de manifestar plenamente a fidelidade de Deus, que permanece fiel, apesar do seu Povo, sempre infiel. Esta mensagem exigente, nós cristãos devemos comunicar colocando-nos de joelhos e dizendo humildemente que uma Palavra do Senhor, e não uma palavra humana, uma Palavra que anunciamos sem presunção, nem arrogância, reconhecendo que viver o matrimônio na fidelidade e no amor re- 
novado é uma obra pastoral árdua, difícil, fadigosa, impossível sem o auxílio da graça de Deus e, em todos os casos, jamais vivida plenamente, mas sempre contradita pelas nossas misérias, fraquezas e atitude egoísta que nos acompanham, em nossa dramaticidade histórica.

A Exortação reconhece que este anúncio evangélico não pode, com certeza, ser alterado pelo magistério, ainda que isto cause escândalo não somente no mundo, mas nos próprios cristãos do nosso tempo. Diante desta verdade fundante, a pastoral familiar deve anunciá-la, sem alterar a doutrina, deve ter a coragem de exprimi-la com palavras novas, compreendendo cada vez melhor tal anúncio. Se por um lado reconhecemos que o Evangelho não muda, por outro sabemos e desejamos que precisamos compreendê-lo melhor.

Por isto, a pastoral familiar que se inspira em Amoris Laetitia, na convicção que a forma e a identidade da família, muito diversificada nas diversas sociedades e culturas contemporâneas, conheceu profundos e rápidos câmbios, põe-se à escuta das famílias que vivem um modo novo em relação ao passado. A pastoral familiar deve dialogar com as mulheres e homens de nosso tempo, reconhecendo as suas fragilidades ao constituírem as experiências familiares, mas também, os medos e as incertezas com relação à experiência familiar.

Somente a escuta atenta, amorosa, não presunçosa da atual fadiga em construir e viver a experiência familiar pode nascer um olhar sobre esta experiência marcado por alegre esperança, mas, ao mesmo tempo, marcado por sofrimento e dor. De fato, hoje, muitos cristãos se encontram nessa situação de sofrimento, de laceração. A presença deles no tecido eclesial deve interrogar a pastoral familiar, porque nem todos, após a separação são capazes de viver em solidão, numa situação de castidade.

Paradoxalmente, estas separações nos fazem conhecer histórias de amor que recomeçam e que, algumas vezes, se mostram mais fecundas e mais sólidas do que as vividas precedentemente. Diante desta situação paradoxal, a pastoral familiar é chamada a compreender que não pode ter o comportamento de considerar estas pessoas como pecadoras e concubinas. É preciso desejar que estas pessoas encontrem acolhida na Igreja, não sejam julgadas, mas recebam o olhar misericordioso e fraterno de uma comunidade de santos/pecadores, uma casta meretriz, onde a única diferença que pode ser evidenciada é a de que alguns pecados são manifestos, enquanto que a maior parte dos nossos pecados permanecem escondidos. 
A pastoral familiar precisa aprender a ter o olhar misericordioso e humano de Jesus que vê o amor lá onde os religiosos de seu tempo veem o pecado. É preciso aprender, também, o amor e não somente o pecado, na situação em que homens e mulheres se empenham, muitas vezes de modo sofrível, limitado e contraditório, em dar forma a histórias de amor. Por trás dessas situações "irregulares", normalmente apresenta-se a humana busca pelo amor, o desejo de amar e ser amado. E do amor, o ser humano não pode jamais envergonhar-se. Assim, a lógica da pastoral familiar deve ser uma lógica regenerativa, enquanto é capaz de gerar a vida nova e regenerar o amor ferido. Cremos profundamente que nesta generatividade radica-se a nossa esperança pastoral.

\section{Referências bibliográficas}

CELAM. Documento de Aparecida. Texto conclusivo da V Conferência Geral do Episcopado Latino-americano e do Caribe. Brasília/São Paulo/São Paulo: CNBB/Paulus/Paulinas, 2007.

COMISSIONE TEOLOGICA INTERNAZIONALE. "Magistero e teologia". Disponível em: <www.vatican.va>. Acesso em 26 de setembro de 2016.

CONCÍLIO VATICANO II. Constituição Dogmática Lumen Gentium sobre a Igreja. São Paulo: Paulinas, 1998.

CONCÍLIO VATICANO II. Constituição pastoral Gaudium et spes sobre a Igreja no mundo de hoje. São Paulo: Paulinas, 1998.

CONGREGAÇÃO PARA A DOUTRINA DA FÉ. "Instrução Donum Veritatis sobre a vocação eclesial do teólogo". Disponível em: <www.vatican. va>. Acesso em 26 de setembro de 2016.

FRANCISCO. Exortação apostólica pós-sinodal Amoris Laetitia sobre o amor na família. Loyola: São Paulo, 2016.

FRANCISCO. "Exortação Apostólica Evangelii Gaudium sobre o anúncio do Evangelho no mundo actual". Disponível em: <www.vatican.va>. Acesso em 26 de setembro de 2016.

JOÃO PAULO II. Carta encíclica Redemptor Hominis. São Paulo: Paulinas, 1980. 
MORAES, A. "Família, 'lugar primeiro' da transmissão da fé: desafios catequéticos a partir do magistério". Perspectiva Teológica 131 (2015), pp. 71-88.

Abimar Oliveira de Moraes Doutor em Teologia pela Università Pontificia Salesiana de Roma Professor de Teologia na PUC-Rio Rio de Janeiro / RJ - Brasil E-mail: abimar@puc-rio.br

Recebido em: 13/10/16 Aprovado em: 14/10/16 